\section{Cartilha: Saúde mental e direitos humanos}

Associação Brasileira de Familiares, Amigos e Portadores de Esquizofrenia e Centro de Direitos Humanos. São Paulo; 2009.

Indiscutivelmente, o progresso da Psiquiatria, sobretudo nas últimas décadas, propiciou tratamentos mais efetivos que, juntamente com novos pactos sociais, permitiram aproximar o indivíduo com transtorno mental da sociedade, visando a sua inclusão. Na prática clínica, frequentemente se observa que os problemas psicossociais podem desenvolver-se em consequência do quadro psicopatológico ou, em outras tantas vezes, podem constituir problemas que devem ser considerados no plano terapêutico global. A falta de informação agrava as dificuldades enfrentadas pelas pessoas com transtornos mentais, muitas vezes resultando no conhecido e perigoso ciclo vicioso: preconceito estigma - exclusão social. Tal situação também configura mais um obstáculo para o exercício integral dos seus direitos, pois o desconhecimento destes faz com que não sejam legitimamente reclamados e, tampouco, de fato, exercidos. Infelizmente, apesar da notória importância do assunto, a literatura disponível ainda é escassa.

Dentro deste contexto, a parceria entre duas importantes organizaçóes, cada uma delas referência na sua área, a Associação

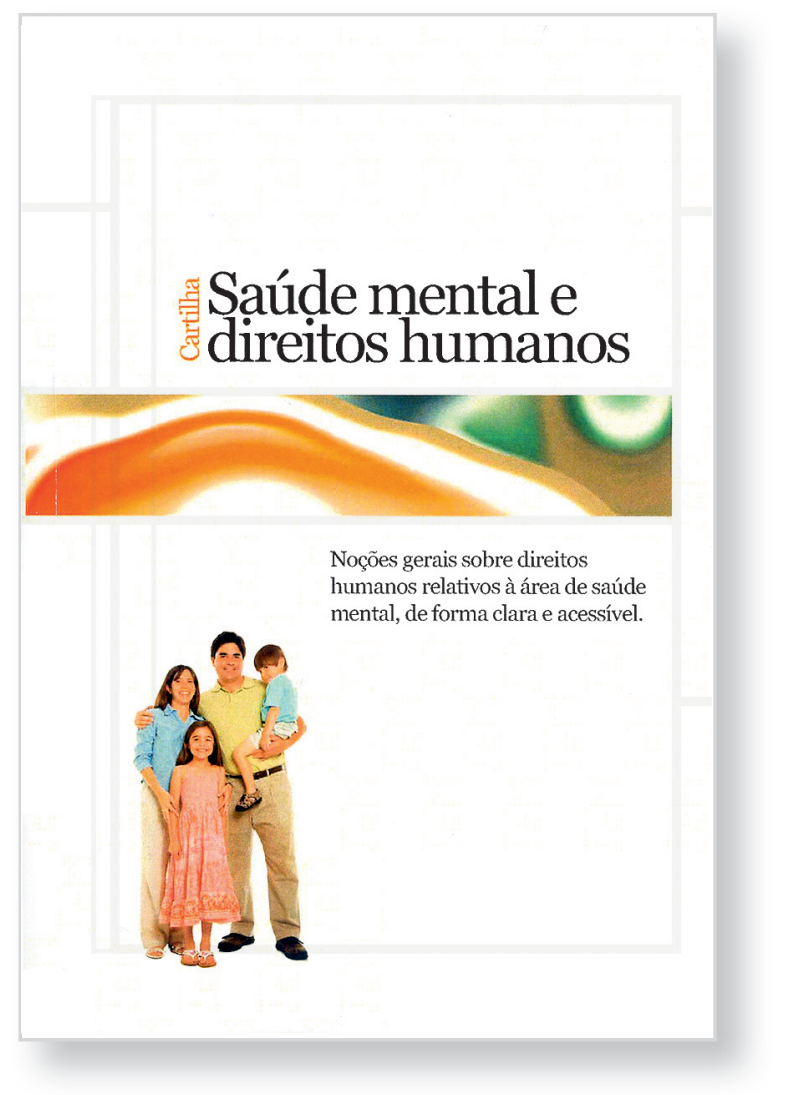

Brasileira de Amigos, Familiares e Portadores de Esquizofrenia (ABRE) e o Centro de Direitos Humanos (CDH) produziu a recente publicação: Cartilha "Saúde mental e direitos humanos".

Estruturado em sete partes - Saúde Mental e Direitos Humanos, Saúde Mental no Direito, Sistema de Atenção em Saúde Mental, Benefícios Destinados às Pessoas com Transtorno Mental, Saúde Mental nos Tribunais, Órgãos Responsáveis e Informaçōes Úteis -, o livro apresenta um texto em linguagem clara, objetiva e acessível, além de um conteúdo abrangente e profundo que versa sobre os direitos relativos à saúde mental, dispersos em várias áreas do Direito, como civil, penal, trabalhista e previdenciário.

O formato facilita o manuseio e as consultas. Os capítulos descrevem, de modo sintético e eficaz, a evolução dos processos que culminaram nas conquistas dos direitos. Declaraçōes, leis específicas, resoluçōes e jurisprudências subsidiam as informaçōes às pessoas que não atuam exclusivamente na área jurídica. Porém, o que mais chama a atenção é a maneira objetiva e didática com que os assuntos são tratados - desde a mais simples orientação sobre isenção tarifária no transporte público ao conceito de imputabilidade penal, passando por auxílio-doença e aquisição de medicamentos, por exemplo. As respostas para estas questōes eminentemente práticas são facilmente encontradas, destacando-se pela completude, o que revela a minúcia do trabalho realizado. Vale ressaltar, também, o alcance nacional da obra, uma vez que foram compiladas informaçôes referentes a todos os Estados da União.

Tais características, consequentemente, tornam esta publicação uma referência no assunto nos dias atuais. Certamente, será útil em dúvidas de todos profissionais envolvidos na assistência psiquiátrica em quaisquer níveis de atenção, assim como familiares e amigos de pessoas com transtorno mental e, principalmente, destes em sua luta pelo direito à igualdade, à dignidade e a não discriminação, por meio do exercício da sua cidadania.

Informações sobre a Cartilha "Saúde mental e direitos humanos" estarão disponíveis eletronicamente no endereço: www.abrebrasil. org.br

Gustavo Machado Barros

Departamento de Psiquiatria, Universidade Federal de São Paulo (UNIFESP), São Paulo (SP), Brasil 